\title{
Production, chemical composition and prostaglandin F-2 $\alpha$ content of uterine fluid in pregnant sheep
}

\author{
F. A. Harrison, R. B. Heap and N. L. Poyser* \\ A.R.C. Institute of Animal Physiology, Babraham, Cambridge CB2 4AT, and \\ *Department of Pharmacology, University of Edinburgh, 1 George Square, Edinburgh, U.K.
}

\begin{abstract}
Summary. A uterine pouch was prepared surgically in ewes before mating to study the production and chemical composition of uterine secretions during pregnancy. Pregnancy was established in 6 sheep and in the first 55 days uterine fluid was present in small amounts $(<5 \mathrm{ml})$, whereas between 109 days post coitum and 3 days post partum the volume ranged from 90 to $775 \mathrm{ml}$.

The chemical composition of uterine fluid in pregnancy differed from that of plasma especially in respect of its high concentration of total calcium (up to $83.5 \mathrm{~mm}$ ) and prostaglandin (PG) F-2 $\alpha$ (up to $1500 \mathrm{ng} / \mathrm{ml}$ ). Progesterone was implicated as an important endocrine factor since uterine fluid $(188 \mathrm{ml})$ with a high concentration of total calcium ( $53.5 \mathrm{mM})$ and PGF- $2 \alpha(235 \mathrm{ng} / \mathrm{ml})$ was recovered from a non-pregnant sheep treated with progesterone for 115 days.
\end{abstract}

\section{Introduction}

In non-pregnant sheep with an ovary or uterus transplanted to the neck, the corpus luteum persists, plasma progesterone remains elevated (Goding, Harrison, Heap \& Linzell, 1967) and in some animals fluid containing a high concentration of prostaglandin (PG) F-2 $\alpha$ accumulates within the lumen of the uterus (Harrison, Heap, Horton \& Poyser, 1972). Amoroso (1954) briefly reported that when one horn of the uterus was isolated from the body of the uterus and pregnancy was established in the unoperated side, fluid accumulated in the lumen of the isolated horn.

The present study was intended to define the accumulation of fluid in a uterine pouch during pregnancy and examine the possibility that the fluid also contained PGF- $2 \alpha$ when produced under the influence of maintained high levels of progesterone. The chemical composition of the fluid was also determined. A preliminary account of part of this work has been published (Amoroso, Harrison, Heap \& Poyser, 1973).

\section{Materials and Methods}

\section{Animals}

Seven Merino $\times$ Welsh Mountain $\times$ Clun Forest ewes aged 2-4 years were used. Five sheep had completed 1 or 2 pregnancies. The ewes were housed in individual pens and were fed a diet of chaffed hay $(1000 \mathrm{~g})$ and crushed oats $(200 \mathrm{~g})$ once daily, with free access to water and a mineral salt lick.

\section{Operative and sampling procedures}

Mid-ventral laparotomies were performed under general anaesthesia induced with intravenous pentobarbitone sodium $(60 \mathrm{mg} / \mathrm{ml}$ in saline) and continued in a closed circuit re-breathing system with mixtures of oxygen and halothane (Fluothane: I.C.I. Ltd, Macclesfield). A uterine pouch was prepared by the following technique. The myometrium of one uterine horn near to the body of the 
uterus was incised transversely over about half its circumference and the endometrium completely transected. The cut ends of the endometrium were sutured separately with continuous Cushing and Connell inverting mattress sutures ( $2 / 0$ chromic catgut mersuture) to create a double-walled septum which isolated the horn from the body of the uterus (see Text-fig. 1). The myometrium was then closed with a continuous catgut suture.

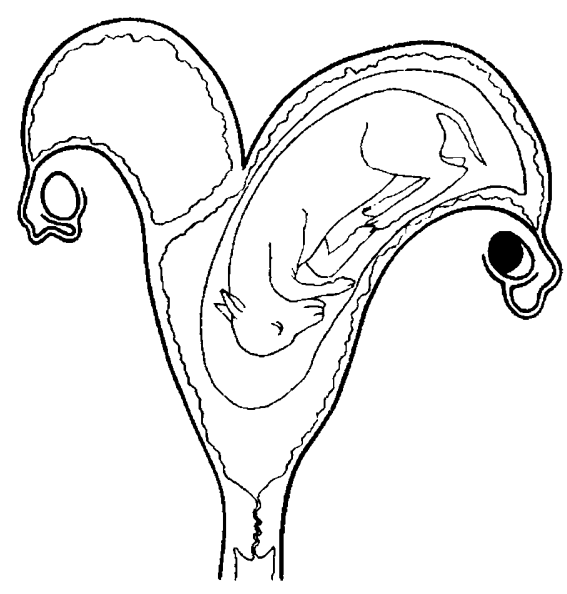

Text-fig. 1. Diagram of the uterine pouch formed in a ewe by a septum of endometrium which excluded fetal membranes from one horn of the uterus.

After recovery from surgery, the ewes were mated with a raddle-harnessed fertile ram to establish pregnancies with accurate mating dates. Laparotomies were performed at different times of gestation and at most operations the fluid in the isolated pouch was aspirated and its volume measured. After a sample had been taken the remainder of the fluid was returned to the lumen of the pouch.

In the ewe, Nymph, a catheter was implanted into the pouch after draining $180 \mathrm{ml}$ fluid on Day 113 post coitum (p.c.). One non-pregnant ewe (Minx) with the left ovary removed was injected i.m. with progesterone (Organon Laboratories Ltd) at $10 \mathrm{mg} /$ day for 8 days then $20 \mathrm{mg} /$ day for 107 days.

Jugular blood samples were taken during gestation, and also just before laparotomy when a jugular vein was temporarily catheterized. In some animals, samples of uterine blood were also taken from the isolated horn by needle puncture at laparotomy. In one ewe (Mo) a permanent sampling catheter (vinyl tube NT3 SH95: Portex Ltd, Hythe, Kent) was implanted into the utero-ovarian vein during the last third of pregnancy. This catheter was kept patent by daily flushing with sterile heparin saline ( $5 \mathrm{ml}$ of 500 i.u. heparin/ml saline).

During recovery from laparotomy protective treatment against the effects of surgery on endogenous progesterone production (Bedford, Harrison \& Heap, 1973) and cardiovascular changes associated with shock included i.m. injections of progesterone to pregnant ewes in decreasing doses over 3 days (usually 15,10 and $5 \mathrm{mg} /$ day) and, after 100 days of gestation, i.m. injections of $25 \mathrm{mg}$ cortisone acetate immediately after operation and of $12.5 \mathrm{mg}$ the following day. Intravenous fluid therapy with dextrose-saline $(4.3 \%$ dextrose, $0.18 \% \mathrm{NaCl}$ ) was given (up to 1 litre/day in divided doses) during the first 2 days of post-operative recovery in late pregnancy.

\section{Analytical procedures}

Prostaglandins in uterine fluid and plasma were extracted by solvents, assayed biologically and identified by gas chromatography and mass spectrometry as described by Blatchley, Donovan, Horton \& Poyser (1972), Poyser (1974) and Downie, Poyser \& Wunderlich (1974). Prostaglandin F-2 $\alpha$ was also measured by a direct radioimmunoassay of $200 \mu$ l diluted uterine fluid or plasma extracted with ethyl acetate, after the addition of an equal volume of $5 \%$ formic acid. The assay 
technique was identical to that described by Sharma, Hibbard, Hamlett \& Fitzpatrick (1973). The antiserum $160 \cdot 3$ (kindly provided by Dr M. Withnall, May \& Baker Ltd, Dagenham) was raised in a sheep against PGF- $2 \alpha$ conjugated to bovine serum albumin and used at a titre of 1 in 3000 . The crossreaction against PGF-1 $\alpha$ was $27.2 \%$, PGE- $2<0.1 \%$, and PGA-2 and PGE- $1<0.01 \%$.

Progesterone was measured by Method A of Heap, Gwyn, Laing \& Walters (1973).

Total unconjugated oestrogens were measured by the method of Challis, Heap \& Illingworth (1971).

Total nitrogen was determined in an aliquot of the whole fluid after mixing in an Ultra-Turrax homogenizer (Janke \& Kunkel KG, Staufen, Germany).

Total soluble nitrogen was estimated in the supernatant from low-speed centrifugations of an aliquot of fluid. Soluble protein nitrogen was calculated by subtraction of the soluble non-protein nitrogen estimated after protein precipitation using an equal volume of $20 \%$ trichloracetic acid. Micro-Kjeldahl digestions $(0 \cdot 1-0.2 \mathrm{ml})$ were performed at $320^{\circ} \mathrm{C}$ for $17 \mathrm{hr}$ using a mercury catalyst and the ammonia-nitrogen estimated with a Technicon autoanalyzer (Technicon Instruments Co. Ltd, Basingstoke, Hants) (West \& Mangan, 1973).

Cation estimations were made by flame photometry; $\mathrm{Na}^{+}$and $\mathrm{K}^{+}$using a Technicon flame photometer with internal lithium standard and flame emission detection; $\mathrm{Mg}^{2+}$ and $\mathrm{Ca}^{2+}$ by atomic absorption flame spectrophotometry using an SP 90 instrument (Pye Unicam Ltd, Cambridge).

\section{Results}

\section{Establishment of pregnancy in sheep with an isolated uterine horn}

Pregnancy was established in 6 animals and gestation continued for $148 \pm 0 \cdot 5$ days in 4 of them. Normal delivery of female lambs occurred in two sheep at 149 (Mo, pouch in left horn) and 148 (Mimi, pouch in right horn) days p.c. In a third animal (Nymph), the conceptus (including the fetal membranes), was found to be confined to the isolated left horn, presumably because of penetration of the endometrial septum by spermatozoa at the time of mating; a live fetus was carried to term and was delivered by Caesarean section after dystocia developed. In the fourth animal (Niobe, pouch in right horn), there were no measurable circulating oestrogens $(<10 \mathrm{pg} / \mathrm{ml})$ in jugular plasma samples at 148 days p.c.; laparotomy performed 149 days p.c. revealed a dead fetus in utero with a degenerating placenta. In the fifth animal (Nadia) laparotomy 99 days p.c. showed that pregnancy had been established in the unoperated left horn, but the membranes had penetrated the septum and invaded the isolated horn. The sixth ewe (Norma) in which an isolated uterine pouch had been prepared in the left horn was not pregnant at 143 days p.c. Resorption had probably occurred since at 38 days p.c. the plasma progesterone concentration was $2 \mathrm{ng} / \mathrm{ml}$, indicating the presence of a viable conceptus, whereas at 87 days p.c. it was only $0.7 \mathrm{ng} / \mathrm{ml}$ a value similar to those in non-pregnant sheep. At laparotomy on Day 143 p.c. there was a persistent corpus luteum in the right ovary.

\section{Accumulation of uterine fluid}

The volumes of uterine fluid recovered at various times of gestation are given in Table 1. At the earliest laparotomy on Day 45 p.c. $5 \mathrm{ml}$ fluid were aspirated, but in animals examined at 55 and 57 days p.c. no fluid could be recovered from the isolated uterine horn. Fluid accumulation was evident in all sheep examined after 109 days of pregnancy. The greatest volume recovered $(775 \mathrm{ml})$ was from sheep Mo 1 day after birth of a normal lamb. In Mimi a smaller volume was recovered $(90 \mathrm{ml}) 3$ days after parturition.

In all experiments the uterine fluid recovered had a similar and characteristic appearance. It was opaque, odourless and sterile, as indicated by the absence of bacterial growth on blood agar for 24 and $48 \mathrm{hr}$. 
Table 1. Volumes of uterine fluid measured at laparotomy and prostaglandin F-2 $\alpha$ concentrations measured by bioassay and radioimmunoassay (in parentheses) in sheep with a uterine pouch

\begin{tabular}{|c|c|c|c|c|}
\hline \multirow[b]{2}{*}{ Exp. } & \multirow[b]{2}{*}{$\begin{array}{l}\text { Sheep and condition* } \\
\text { (days post coitum) }\end{array}$} & \multirow[b]{2}{*}{$\begin{array}{l}\text { Vol. of fluid } \\
\quad(\mathrm{ml})\end{array}$} & \multicolumn{2}{|c|}{ PGF-2 $\alpha$} \\
\hline & & & $\begin{array}{l}\text { Concn } \\
(\mathrm{ng} / \mathrm{ml})\end{array}$ & $\begin{array}{c}\text { Amount } \\
(\mu \mathrm{g} / \text { isolated } \\
\text { horn })\end{array}$ \\
\hline 1 & Niobe, P 45 & 5 & $28 \cdot 5 \dagger$ & $0 \cdot 1$ \\
\hline 2 & Nadia, P 55 & nil & nil & nil \\
\hline 3 & Nymph, P 57 & nil & nil & nil \\
\hline 4 & Nadia, P 99 & nil & nil & nil \\
\hline 5 & Mo, P 109 & 175 & $41 \cdot 6 \dagger$ & $7 \cdot 3$ \\
\hline 6 & Nymph, P 113 & 180 & $111 \cdot 0+(200)$ & $20 \cdot 0$ \\
\hline 7 & Niobe, P 122 & $10 \ddagger$ & $33 \cdot 3$ & - \\
\hline 8 & Nymph, P 124 & $12 \S$ & $218 \cdot 2 \dagger$ & - \\
\hline 9 & Niobe, P 149 & 127 & $1500 \cdot 0+(1680)$ & $190 \cdot 5$ \\
\hline 10 & Mo, P 149 + PP 1 & 775 & $404 \cdot 8+(413)$ & $313 \cdot 7$ \\
\hline 11 & Mimi, P 148 + PP 3 & 90 & $11.9+(6.3)$ & $1 \cdot 1$ \\
\hline \multirow[t]{3}{*}{12} & Norma, NP 143 & & & \\
\hline & Left horn & 700 & $3 \cdot 2 \dagger$ & $2 \cdot 2$ \\
\hline & Right horn & 143 & $<1.9(0 \cdot 1)$ & $<0.3$ \\
\hline \multirow[t]{2}{*}{13} & Minx, NP + progesterone for & & & \\
\hline & 115 days $\llbracket$ & 188 & $235.0 \dagger(382 \cdot 0)$ & $42 \cdot 5$ \\
\hline
\end{tabular}

* P, pregnant; NP, not pregnant; PP, post partum.

† Identity confirmed by gas chromatography-mass spectrometry.

¥ Volume not measured, aliquot only.

$\$$ Sample obtained through indwelling uterine catheter.

T $10 \mathrm{mg} /$ day for 8 days, $20 \mathrm{mg} /$ day for 107 days.

\section{Prostaglandins}

All samples of uterine fluid recovered from pregnant or post-parturient ewes contained PGF-2 $\alpha$ as indicated by bioassay and radioimmunoassay and in 8 samples examined its identity was confirmed by GC-MS (Table 1). The amounts in the other two samples examined were too low for identification. There was no evidence of PGs of the E series. High values of PGF- $2 \alpha$ were recorded around the time of parturition (see values for Mo at 109 days of gestation and on the day after normal parturition (Table 1)). The PGF-2 $\alpha$ values in the fluid samples from the isolated pouch and the rest of the uterus of Norma were low.

No PGF- $2 \alpha$ was detected by bioassay $(<2 \mathrm{ng} / \mathrm{ml})$, GC-MS or radioimmunoassay $(<0.5 \mathrm{ng} / \mathrm{ml})$ in jugular vein plasma collected in Exps $1,3,5,6,8$ or 9 (Table 1), or in uterine vein blood draining from the uterine pouch (Exps 3, 4, 5 and 7).

\section{Effect of progesterone on the accumulation of uterine fluid and its PGF-2 $\alpha$ content in a non-pregnant sheep}

In the ewe Minx, progesterone was injected daily during the normal breeding season; no behavioural oestrus was observed. Laparotomy after 115 days of progesterone treatment revealed a uterus distended by $188 \mathrm{ml}$ of fluid which resembled that found in the pouches of pregnant ewes (present study) and that from non-pregnant ewes with an autotransplanted ovary or uterus (Harrison et al., 1972). The concentration of PGF-2 $\alpha$ in the uterine fluid was high (Table 1). In this animal, a sample of uterine vein plasma collected at laparotomy under anaesthesia contained a significant concentration of PGF- $2 \alpha(9.4 \mathrm{ng} / \mathrm{ml}$ by bioassay, identity confirmed by GC-MS; $2.4 \mathrm{ng} / \mathrm{ml}$ radioimmunoassay), and negligible amounts in jugular vein plasma $(<2.9$ and $<0.1 \mathrm{ng} / \mathrm{ml}$, by bioassay and radioimmunoassay respectively). 


\section{Electrolyte and protein composition of fluid}

Table 2 gives the electrolyte and protein concentration of uterine fluid collected during the last third of pregnancy. The most notable finding was a high concentration of calcium, especially in fluid recovered at 149 days p.c. (Niobe). The $\mathrm{Na} / \mathrm{K}$ ratio of uterine fluid differed from that of plasma during the last third of gestation, showing a gradual decline and decreasing further immediately post partum. In non-pregnant sheep the $\mathrm{Na} / \mathrm{K}$ ratio was lower than that of plasma and in fluid from the uterine pouch of Norma and in that from the unilaterally ovariectomized ewe (Minx) treated with progesterone the ratio was similar. The concentration of $\mathrm{Na}$ and $\mathrm{K}$ in uterine fluid recovered during the last third of pregnancy differed markedly from that in amniotic or allantoic fluids (Table 2).

Table 2. Concentration of some chemical constituents of uterine fluids recovered from sheep during pregnancy and from a non-pregnant sheep treated with progesterone

\begin{tabular}{|c|c|c|c|c|c|c|c|}
\hline $\begin{array}{l}\text { Sheep and condition* } \\
\text { (days post coitum) }\end{array}$ & $\begin{array}{c}\text { Total } \\
\text { nitrogen } \\
(\mathrm{mg} / \mathrm{ml})\end{array}$ & $\begin{array}{l}\text { Soluble protein } \\
\text { nitrogen } \\
(\mathrm{mg} / \mathrm{ml})\end{array}$ & $\begin{array}{c}\mathrm{Na} \\
(\mathrm{mM})\end{array}$ & $\underset{(\mathrm{mM})}{\mathrm{K}}$ & $\begin{array}{c}\mathrm{Mg} \\
(\mathrm{mM})\end{array}$ & $\underset{(\mathrm{mM})}{\mathrm{Ca}}$ & $\begin{array}{l}\mathrm{Na} / \mathrm{K} \\
\text { ratio }\end{array}$ \\
\hline Mo, P 109 & - & - & $30 \cdot 8$ & 0.29 & $1 \cdot 59$ & $2 \cdot 8$ & $106 \cdot 2$ \\
\hline $\begin{array}{l}\text { Nymph, P } 113 \\
\text { (non-gravid horn) }\end{array}$ & $10 \cdot 1$ & $5 \cdot 0$ & $17 \cdot 6$ & $0 \cdot 24$ & $1 \cdot 85$ & $54 \cdot 8$ & $73 \cdot 3$ \\
\hline Niobe, P 149 & $10 \cdot 8$ & $3 \cdot 8$ & $10 \cdot 1$ & 0.18 & $2 \cdot 50$ & $83 \cdot 5$ & $56 \cdot 1$ \\
\hline Mo, P 149 + PP 1 & $7 \cdot 1$ & $2 \cdot 8$ & $8 \cdot 8$ & $0 \cdot 32$ & $2 \cdot 63$ & $49 \cdot 5$ & $27 \cdot 5$ \\
\hline $\begin{array}{l}\text { Mimi, P } 148+\text { PP } 3 \\
\text { Norma, NP } 143\end{array}$ & $5 \cdot 2$ & $2 \cdot 5$ & $78 \cdot 6$ & $3 \cdot 40$ & $1 \cdot 20$ & $28 \cdot 7$ & $23 \cdot 1$ \\
\hline Left horn & - & - & $26 \cdot 0$ & $44 \cdot 80$ & $1 \cdot 34$ & $15 \cdot 2$ & 0.6 \\
\hline Right horn & $2 \cdot 0$ & $0 \cdot 8$ & $98 \cdot 2$ & $16 \cdot 90$ & 0.48 & $19 \cdot 4$ & $5 \cdot 8$ \\
\hline $\begin{array}{l}\text { Minx, NP + progesterone } \\
\text { for } 115 \text { days } \dagger\end{array}$ & $6 \cdot 4$ & $2 \cdot 2$ & 18.4 & $4 \cdot 52$ & $2 \cdot 22$ & $53 \cdot 5$ & $4 \cdot 1$ \\
\hline $\begin{array}{l}\text { Plasma } \\
\text { Amniotic fluid }\end{array}$ & $11 \cdot 4$ & $11 \cdot 2$ & $150 \cdot 2 \ddagger$ & $5 \cdot 90 \$$ & $0.83 \ddagger$ & $2 \cdot 41 \ddagger$ & $25 \cdot 5$ \\
\hline $\begin{array}{l}\text { (P } 100 \text { to term) } \\
\text { Allantoic fluid§ }\end{array}$ & 一 & - & $100 \rightarrow 90$ & $5 \rightarrow 15$ & - & - & 一 \\
\hline (P 100 to term) & 一 & - & $100 \rightarrow 20$ & $40 \rightarrow 100$ & 一 & - & - \\
\hline
\end{tabular}

\footnotetext{
* P, pregnant; NP, not pregnant; PP, post partum.

$\dagger 10 \mathrm{mg} /$ day for 8 days, $20 \mathrm{mg} /$ day for 107 days.

‡ Values taken from Field, Weiner \& Wood (1969).

$\S$ Values taken from Mellor \& Slater (1971).
}

\section{Discussion}

In the sheep, implantation of the embryo in one horn is accompanied by the growth of the fetal membranes into the contralateral horn with subsequent attachment to maternal caruncles and the formation of placentomes. This was prevented in our experiments by the construction of an endometrial septum in one horn before mating and establishment of pregnancy. Analysis of the fluid which accumulated in the isolated horn revealed high concentrations of prostaglandins, identified and measured as PGF-2 $\alpha$ by three analytical procedures. These results show that the endogenous hormones of pregnancy can produce the same effect as observed in sheep in which the corpus luteum persists because an ovary or uterus has been transplanted to the neck (Harrison et al., 1972). Similar results were also obtained when a sheep was treated with progesterone for 115 days.

It is notable that it took at least $\mathbf{5 0}$ days for the fluid to accumulate in pregnancy and that the volume of fluid and its PGF- $2 \alpha$ concentration varied considerably between animals. In animals with a transplanted ovary up to $1900 \mathrm{ml}$ fluid and $7.6 \mathrm{mg}$ PGF- $2 \alpha$ were recovered from the uterus (Harrison et al., 1972), whereas in the present work the highest values in a uterine pouch $(775 \mathrm{ml}$ and $313.7 \mu \mathrm{g})$ were recorded in a ewe 1 day after parturition. Fluid accumulation in a uterine pouch during pregnancy was not caused solely by the surgical closure of the horn. In the ewe (Nymph) in which the 
conceptus was located in the uterine pouch, fluid accumulated in the unoperated horn and body of the uterus. Fluid accumulation also occurred in a non-pregnant ewe with an intact uterus when treated with progesterone for a prolonged period. It appears, therefore, that fluid accumulation may be related to an effect of progesterone on cervical closure even when the uterine lumen contains fluid rich in PGF-2 $\alpha$.

The function of uterine fluid in the pregnant sheep is uncertain but it may be that it is either absorbed and metabolized by the allantochorionic membrane, or it may contribute to the nutritive 'histotrophe' described by earlier workers (Bonnet, 1899; see Amoroso, 1952). The changes in the $\mathrm{Na} / \mathrm{K}$ ratio of uterine fluid recovered during our experiments indicate the occurrence of secretory mechanisms that are influenced by the endocrine status and recall earlier observations of an increase in concentration of $\mathrm{K}$ found in uterine washings recovered from sheep during the luteal phase of the oestrous cycle compared with that at oestrus (Heap, 1962). The occurrence of a high concentration of total calcium, at least 10-fold higher than that normally found in plasma, suggests that it is transported against a diffusion gradient as reported for the placental transfer of total plasma calcium from the ewe to the fetus (Bawden, Wolkoff \& Flowers, 1965; Carlyle, 1976). The magnitude of the total calcium concentration in uterine fluid points to the probable occurrence of a calcium-binding protein.

The physiological role of PGF-2 $\alpha$ in the sheep uterus remains ambiguous, though stimulation of myometrial contractility has been frequently implied. It seems improbable that PGF-2 $\alpha$ stimulated myometrial contractions in our preparations in view of the large amount of fluid that accumulated in the uterus, but the effect may have been inhibited by the circulating level of progesterone normally found in pregnancy (Bedford, Harrison \& Heap, 1972).

We acknowledge the skilled technical assistance of Miss Grace Needham, and $\mathrm{Mr}$ J. Christie, Mr A. Henville, Mr D.J. Jordan and Mr R.C. Saunders. We thank Dr J.L. Mangan for the measurement of total nitrogen and soluble protein nitrogen, Mr G.A. Embleton for bacteriological tests and Mrs L. Bowles for typing.

\section{References}

AMoroso, E.C. (1952) Placentation. In Marshall's Physiology of Reproduction, vol. 2, pp. 152-311. Ed. A.S. Parkes. Longmans, London.

Amoroso, E.C. (1954) Discussion of paper entitled "Problems of sugar transport in the placenta of the ungulate" by Huggett, A. St. G. In Gestation, Transactions of the First Conference, p. 68. Ed. C.A. Villee. The Josiah Macy, Jr Foundation, Publications, New York.

Amoroso, E.C., Harrison, F.A., Heap, R.B. \& Poyser, N.L. (1973) The production of prostaglandin $F_{2 x}$ by the uterus of the sheep. $J$. Endocr. 57, lix.

BAwden, J.F., Wolkoff, A.S. \& Flowers, C.E. (1965) Maternal-fetal blood calcium relationships in sheep. Obstét. Gynéc. 25, 548-552.

Bedford, C.A., Harrison, F.A. \& Heap, R.B. (1972) The metabolic clearance rate and production rate of progesterone and the conversion of progesterone to 20 $\alpha$-hydroxypregn-4-en-3-one in the sheep. $J$. Endocr. 55, 105-118.

Bedford, C.A., Harrison, F.A. \& Heap, R.B. (1973) The kinetics of progesterone metabolism in the pregnant sheep. In The Endocrinology of Pregnancy and Parturition-Experimental Studies in the Sheep, pp. 83-93. Ed. C.G. Pierrepoint. Alpha Omega Alpha, Cardiff.
Blatchley, F.R., Donovan, B.T., Horton, E.W. \& POYSER, N.L. (1972) The release of prostaglandins and progestin in the utero-ovarian venous blood of guinea-pigs during the oestrous cycle and following oestrogen treatment. J. Physiol., Lond. 223, 69-88.

Carlyle, S.S. (1976) Transplacental total and ionic calcium gradients in conscious sheep. J. Physiol., Lond. 254, 14P-15P.

Challis, J.R.G., Heap, R.B. \& Illingworth, D.V. (1971) Concentrations of oestrogen and progesterone in the plasma of non-pregnant, pregnant and lactating guinea-pigs. $J$. Endocr. 51, 333-345.

Downie, J., POyser, N.L. \& Wunderlich, M. (1974) Levels of prostaglandins in human endometrium during the normal menstrual cycle. J. Physiol., Lond. 236, 465-472.

Field, A.C., WeINer, G. \& Wood, J. (1969) The concentration of minerals in the blood of genetically diverse groups of sheep. II. Calcium, phosphorus, magnesium, potassium, sodium and chloride concentrations for three half-breeds and their crosses at pasture. J. agric. Sci., Camb. 73, 267-274.

Goding, J.R., Harrison, F.A., HeaP, R.B. \& Linzell, J.L. (1967) Ovarian activity in the ewe after autotransplantation of the ovary or uterus to the neck. J. Physiol., Lond. 191, 129P-130P. 
Harrison, F.A., Heap, R.B., Horton, E.W. \& Poyser, N.L. (1972) Identification of prostaglandin $F_{2 \alpha}$ in uterine fluid from the non-pregnant sheep with an autotransplanted ovary. J. Endocr. 53, 215-222.

HEAP, R.B. (1962) Some chemical constituents of uterine washings: a method of analysis with results from various species. $J$. Endocr. 24, 367-378.

HeAP, R.B., GWyn, M., LaING, J.A. \& Walters, D.E. (1973) Pregnancy diagnosis in cows; changes in milk progesterone concentration during the oestrous cycle and pregnancy measured by a rapid radioimmunoassay. J. agric. Sci., Camb. 81, 151-157.

MelloR, D.J. \& Slater, J.S. (1971) Daily changes in amniotic and allantoic fluid during the last three months of pregnancy in conscious, unstressed ewes, with catheters in their foetal fluid sacs. J. Physiol., Lond. 217, 573-604.

POYSER, N.L. (1974) Some aspects of prostaglandins in reproduction. Biochem. Soc. Trans. 2, 1196-1200.

Sharma, S.C., Hibbard, B.M., HamletT, J.D. \& FitzPatrick, R.J. (1973) Prostaglandin $F_{2 \alpha}$ concentrations in peripheral blood during the first stage of normal labour. Br. med.J. 1, 709-711.

West, J. \& Mangan, J.L. (1973) A comparison of glutaraldehyde and formaldehyde fixation of isolated pea chloroplasts and its implications for the treatment of herbage for nutritional studies. J. agric. Sci., Camb. 80, 399-406.

Received 19 January 1976 